\title{
Living with hepatitis $C$, multiple issues to face
}

\author{
Mathilde Coudray, Elisabete de Carvalho \\ From 17th International Symposium on HIV and Emerging Infectious Diseases (ISHEID) \\ Marseille, France. 23-25 May 2012
}

\begin{abstract}
Aims
Since 2010, viral hepatitis has been declared a public health priority, although it remains little known to the general population. In France, 220.000 people are positive to the hepatitis $\mathrm{C}$ virus (HCV) and live with its chronic form, but limited data exists. This study was undertaken to assess the current face of the epidemic in France, and to identify the profiles of people living with $\mathrm{HCV}$ and their specific challenges.
\end{abstract}

\section{Methods}

The survey consisted of a questionnaire accessible from November 2010 to February 2011 on the Hépatites Info Service website, a French hepatitis helpline. Callers meeting the criteria could also complete the questionnaire with a professional counselor on the toll-free line. After 3 months, 165 questionnaires had been collected.

\section{Results}

Participants' backgrounds are diverse with equal female to male ratio, and an average age of 50 . Women are older and more likely to have been infected by blood transfusion prior to 1991 or by medical procedure with early stage diagnosis. Men, however, frequently presume to have been infected through intravenous drug use with late stage diagnosis. For all participants, $\mathrm{HCV}$ treatment presents a major challenge. Almost all (96\%) undergoing or having concluded treatment emphasized difficult side effects: $26 \%$ interrupted treatment early and $69 \%$ took sick leave. Inadequate health insurance, solitude or addiction problems and coping with the social stigma of $\mathrm{HCV}$ infection multiply general difficulties.

\section{Conclusion}

Living with HCV has major and multiple physiological and psychological consequences, in part treatment-associated. Economic and social precarity and solitude amid a context

\footnotetext{
* Correspondence: mcoudray@sida-info-service.org
}

Sida Info Service, Montpellier, France

(c) 2012 Coudray and de Carvalho; licensee BioMed Central Ltd. This is an Open Access article distributed under the terms of the Creative Commons Attribution License (http://creativecommons.org/licenses/by/2.0), which permits unrestricted use, distribution, and reproduction in any medium, provided the original work is properly cited. of discrimination combine to increase the issues confronting HCV positive people. The study has highlighted the diversity of profiles and problems which need to be integrated into a comprehensive care approach.

Published: 25 May 2012

doi:10.1186/1742-4690-9-S1-P52

Cite this article as: Coudray and de Carvalho: Living with hepatitis C multiple issues to face. Retrovirology 2012 9(Suppl 1):P52.

Submit your next manuscript to BioMed Central and take full advantage of:

- Convenient online submission

- Thorough peer review

- No space constraints or color figure charges

- Immediate publication on acceptance

- Inclusion in PubMed, CAS, Scopus and Google Scholar

- Research which is freely available for redistribution

Submit your manuscript at www.biomedcentral.com/submit
C Biomed Central 